\title{
Differential Influence of Components Resulting from Atmospheric-Pressure Plasma on Integrin Expression of Human HaCaT Keratinocytes
}

\author{
Beate Haertel, ${ }^{1}$ Susanne Straßenburg, ${ }^{1}$ Katrin Oehmigen, ${ }^{2}$ Kristian Wende, ${ }^{3}$ \\ Thomas von Woedtke, ${ }^{2}$ and Ulrike Lindequist ${ }^{1}$ \\ ${ }^{1}$ Institute of Pharmacy, Department of Pharmaceutical Biology, University of Greifswald, Friedrich-Ludwig-Jahn-Straße 17, \\ 17487 Greifswald, Germany \\ ${ }^{2}$ Leibniz Institute for Plasma Science and Technology e.V. (INP), Campus PlasmaMed/PlasmaVitro, Felix-Hausdorff-Straße 2, \\ 17489 Greifswald, Germany \\ ${ }^{3}$ ZIK plasmatis, Leibniz Institute for Plasma Sciences and Technologye.V. (INP), Felix-Hausdorff-Straße 2, 17489 Greifswald, Germany
}

Correspondence should be addressed to Beate Haertel; beate.haertel@uni-greifswald.de

Received 2 April 2013; Accepted 10 June 2013

Academic Editor: Maxim E. Darvin

Copyright (C) 2013 Beate Haertel et al. This is an open access article distributed under the Creative Commons Attribution License, which permits unrestricted use, distribution, and reproduction in any medium, provided the original work is properly cited.

\begin{abstract}
Adequate chronic wound healing is a major problem in medicine. A new solution might be non-thermal atmospheric-pressure plasma effectively inactivating microorganisms and influencing cells in wound healing. Plasma components as, for example, radicals can affect cells differently. HaCaT keratinocytes were treated with Dielectric Barrier Discharge plasma (DBD/air, DBD/argon), ozone or hydrogen peroxide to find the components responsible for changes in integrin expression, intracellular ROS formation or apoptosis induction. Dependent on plasma treatment time reduction of recovered cells was observed with no increase of apoptotic cells, but breakdown of mitochondrial membrane potential. DBD/air plasma increased integrins and intracellular ROS. DBD/argon caused minor changes. About 100 ppm ozone did not influence integrins. Hydrogen peroxide caused similar effects compared to $\mathrm{DBD} /$ air plasma. In conclusion, effects depended on working gas and exposure time to plasma. Short treatment cycles did neither change integrins nor induce apoptosis or ROS. Longer treatments changed integrins as important for influencing wound healing. Plasma effects on integrins are rather attributed to induction of other ROS than to generation of ozone. Changes of integrins by plasma may provide new solutions of improving wound healing, however, conditions are needed which allow initiating the relevant influence on integrins without being cytotoxic to cells.
\end{abstract}

\section{Introduction}

Physical plasma has been defined as a completely or partly ionized gas considered as the fourth state of matter. It is characterized by electrons, positive and negative ions, neutral atoms, and neutral or charged molecules, by its temperature, different types of radiation (e.g., UVB), and by electric fields. The generation of nonthermal plasma at atmospheric pressure with a temperature close to room temperature was the basis for treating sensitive materials as, for example, living cells. The development of different plasma sources and devices led to an explosion of research in plasma medicine. First, main focus of plasma application was the improvement of chronic infected wounds [1-3] and disinfection of surgical instruments or catheters [4] since plasma is effective in the inactivation of different microorganisms [5-10] and removal of biofilms [11-13]. Meanwhile, nonthermal plasma was also investigated for application in several other fields, for example, in dental applications, in changing surfaces of medical implants, in treating cancer or dermatological diseases, and in plastic surgery [14-16]. Ex vivo and in vivo investigations demonstrated that neither plasma-induced UV 
radiation nor a temperature increase or formation of radicals had a potential risk to the treated patients and volunteers [1719].

Treating cells in culture with plasma cell detachment with loss of viability, apoptosis, and damage of DNA were observed [20-28]. The extent of observed effects depended on the plasma source (plasma jet or needle and surface or volume $\mathrm{DBD})$, treatment time (plasma dose), and on the process gas (air, argon, or helium).

In wound healing, for development of cancer metastasis or for spreading of cells on the implant surfaces adhesion molecules, as integrins, cadherins, the epidermal growth factor receptor (EGFR), are of importance. These molecules are responsible for adhesion or detachment of cells, for cell signalling, cell migration, and also for growth and differentiation [29-32] and should be influenced by plasma according to the requirements. While in wound healing migration and proliferation of keratinocytes or fibroblasts should be improved, in treating cancer besides induction of apoptosis and growth arrest, inhibition of migration is requested. Aim of a successful plasma treatment is in either case killing of desired cells without harming the surrounding healthy tissue. To fulfil these criteria it is important to know which of the components generated by plasma will cause the required effect.

The purpose of this study was to elucidate how plasma influences the expression of cell surface molecules of keratinocytes (HaCaT cells) as major cell type of the skin promoting adhesion, migration, and proliferation and which of the components resulting from plasma might be responsible for the effects observed. HaCaT cells were treated with plasma generated by surface dielectric barrier discharge (surface DBD) with air or argon as process gas, with ozone and hydrogen peroxide $\left(\mathrm{H}_{2} \mathrm{O}_{2}\right)$ as nonradical reactive oxygen species resulting from plasma. Both ozone and $\mathrm{H}_{2} \mathrm{O}_{2}$ can be converted into radical reactive oxygen species, for example, into the hydroxyl radical which then can further influence treated cells.

\section{Material and Methods}

2.1. Materials. Cell culture flasks (T75) and $60 \mathrm{~mm}$ diameter Petri dishes came from TPP (Trasadingen, Switzerland). RPMI 1640 with L-glutamine, the culture medium used, fetal calf serum (FCS), and sodium azide $\left(\mathrm{NaN}_{3}\right)$ for addition to PBS buffer were purchased from Sigma (Taufkirchen/ Deisenhofen, Germany). Penicillin and streptomycin and trypsin/EDTA solution were obtained from Lonza (Verviers, Belgium) and phosphate buffered saline (PBS) came from PAA (Cölbe, Germany). Hydrogen peroxide $\left(\mathrm{H}_{2} \mathrm{O}_{2}\right)$ was purchased from Roth (Karlsruhe, Germany). Monoclonal antibodies came either from antibodies-online (Aachen, Germany) ( $\alpha_{2}$-integrin (AK-7-PE, CD 49b; $\alpha_{4}$-integrin (9F10$\mathrm{PE}, \mathrm{CD} 49 \mathrm{~d}), \alpha_{6}$-integrin (GoH3-PE, CD49f); $\alpha_{\mathrm{V}}$-integrin (NKI-M9-PE, CD51); $\beta_{3}$-integrin (VI.PL2-FITC, CD61)), AbD Serotec (Düsseldorf, Germany) ( $\alpha_{3}$-integrin (17c6$\mathrm{PE}, \mathrm{CD} 49 \mathrm{c}$ ), eBioscience (Frankfurt, Germany) ( $\beta_{1}$-integrin
(TS2/16-FITC, CD29)), or Biozol (Eiching, Germany) (Ecadherin (67A4-PE, CD324); epidermal growth factor receptor (EGFR, ICR10-FITC)). Annexin-V-Fluos Staining Kit was provided by Roche Diagnostics (Mannheim, Germany) and the fluorescent probe 5-(and-6)-chloromethyl$2^{\prime}, 7^{\prime}$-dichlorodihydrofluorescein diacetate, acetyl ester (CM$\mathrm{H}_{2}$ DCFDA) by Invitrogen (Molecular Probes, Darmstadt, Germany).

2.2. Cell Culture. The nontumorigenic human keratinocyte cell line HaCaT originally derived from normal human adult skin was kindly provided by Professor NE Fusening (DKFZ, Heidelberg, Germany) [33]. The cells were grown in T75 flasks in RPMI 1640 with L-glutamine supplemented with $8 \%$ FCS and 1\% penicillin-streptomycin solution $(10,000 \mathrm{IU} / \mathrm{mL}$ penicillin; 10,000 $\mu \mathrm{g} / \mathrm{mL}$ streptomycin) (RPMI) and maintained at $37^{\circ} \mathrm{C}$ in a humidified atmosphere of $5 \% \mathrm{CO}_{2}$ and 95\% air. HaCaT keratinocytes were subcultured 2 times weekly. The cell line was free of mycoplasmas as tested by PCR.

2.3. Treatment of HaCaT Cells with Plasma, Ozone, or a ROS Inducer. For treatment of cells with nonthermal atmospheric pressure plasma, a surface DBD plasma arrangement based on a setup described by Oehmigen et al. [34] and Haertel et al. [22] with air or argon as working gas was used. In case of using argon plasma a closed DBD arrangement was used and prior to discharge the plasma air was eliminated by gassing with argon. In all experiments at ambient air conditions, a pulsed sinusoidal voltage of $10 \mathrm{kV}$ peak $(20 \mathrm{kHz})$ with a $0.413 / 1.223 \mathrm{~s}$ plasma-on/plasma-off time was used. For experiments in argon atmosphere, a pulsed sinusoidal voltage of $3 \mathrm{kV}$ peak $(40 \mathrm{kHz})$ with a $0.413 / 1.223 \mathrm{~s}$ plasma-on/plasmaoff time was used. The plasma was formed in a thin layer above the structured side which was faced towards the liquid sample [22].

Ozone was generated by a Laboratory Ozoniser (Sander $\mathrm{GmbH}$, Uetze-Eltze, Germany). Ozone concentration was monitored every $6 \mathrm{~s}$ by an FT-IR Fourier transformed infrared spectroscopy (FT-IR) using a multicomponent FTIR gas analyser Gasmet CR-2000 (Ansyco). Ozone concentration above the petri dish with cells in medium was adjusted to about 100 ppm, 400 ppm, 1000 ppm, or 1800 ppm. To ensure that there is only ozone above the cells an empty Petri dish first was used to eliminate air by gassing with argon. The ozone concentration was then adjusted bypassing the cells. Only thereafter cells were exposed to ozone. Negative controls were exposed to $100 \%$ oxygen.

For treatment $1 \times 10^{6}$ cells were seeded in $60 \mathrm{~mm}$ diameter Petri dishes with $4 \mathrm{~mL}$ RPMI and cultured for $24 \mathrm{~h}$ at $37^{\circ} \mathrm{C}$. One hour prior to treatment cell culture medium was changed. Adherent cells were then exposed for $20 \mathrm{~s}$ to $300 \mathrm{~s}$ to surface DBD plasma, for $300 \mathrm{~s}$ to ozone or for $24 \mathrm{~h}$ to $100 \mu \mathrm{M} \mathrm{H}_{2} \mathrm{O}_{2}$. Control cells remained untreated or were treated with $100 \%$ oxygen. Treated $\mathrm{HaCaT}$ cells were cultured for $1 \mathrm{~h}$ or $24 \mathrm{~h}$ at $37^{\circ} \mathrm{C}$. After removing the medium adherent cells were detached by subsequent treatment with PBS/EDTA (10 min) and trypsin/EDTA in $\mathrm{Ca}^{2+} / \mathrm{Mg}^{2+}$-free PBS (final 
concentration: $0.05 \% / 0.1 \% ; 5 \mathrm{~min}$ ) at $37^{\circ} \mathrm{C}$ and centrifuged. The cell pellet was suspended in PBS supplemented with $0.1 \%$ $\mathrm{NaN}_{3}$ and 1\% FCS (FACS-PBS) for measuring cell surface molecules, in Annexin binding buffer (ABP) for detection of apoptosis or in RPMI for measurement of intracellular ROS. Cell number was calculated using a Neubauer chamber.

2.4. Surface Expression of Adhesion Molecules. Surface expression of adhesion molecules on HaCaT cells was determined by flow cytometry using phycoerythrin- (PE-) or fluorescein-isothiocyanate- (FITC-) conjugated monoclonal antibodies [22]. Cells $\left(1 \times 10^{5} / 50 \mu \mathrm{L}\right.$ FACS-PBS $)$ were incubated for $30 \mathrm{~min}$ at $4^{\circ} \mathrm{C}$ with antibodies recognizing $\alpha_{2^{-}}$, $\alpha_{3^{-}}, \alpha_{4^{-}}, \alpha_{6^{-}}, \alpha_{\mathrm{V}^{-}}, \beta_{1^{-}}$, and $\beta_{3^{-}}$-integrins, E-cadherin, and the epidermal growth factor receptor. After washing of cells $400 \mu \mathrm{L}$ FACS-PBS were added. Optimal antibody concentrations varied from $12.5 \mu \mathrm{g} / \mathrm{mL}\left(\alpha_{2}\right.$-integrin) to $50 \mu \mathrm{g} / \mathrm{mL}$ (EGFR).

The results were expressed as percentage of cells which were stained positive (mean \pm SEM). For comparing the intensity of a staining, flow cytometry data were plotted in one-parameter histograms with counts at the $y$-axis (linear scale) and fluorescence intensity at the $x$-axis (4-decade logarithmic scale). The mean fluorescence intensity (MFI) of a staining, which correlates with antigen density, was expressed as arithmetic mean in $\log U$.

2.5. Externalization of Phosphatidylserine. Externalization of phosphatidylserine as sign of apoptosis was measured $1 \mathrm{~h}$ and $24 \mathrm{~h}$ after HaCaT cells have been treated with either plasma or ozone using an Annexin-V-Fluos Staining Kit. Briefly, 1 $\times 10^{5}$ cells were incubated for $15 \mathrm{~min}$ in the dark at room temperature in $100 \mu \mathrm{L}$ labeling solution consisting of $2 \mu \mathrm{L}$ Annexin-V-Fluos and $2 \mu \mathrm{L}$ PI $(50 \mu \mathrm{g} / \mathrm{mL})$ in $100 \mu \mathrm{L} \mathrm{ABP}$. After incubation $400 \mu \mathrm{L}$ ABP were added and apoptosis was measured within $30 \mathrm{~min}$.

2.6. Intracellular Reactive Oxygen Species (ROS). Intracellular ROS were detected $1 \mathrm{~h}$ and $24 \mathrm{~h}$ after the cells were exposed to plasma using the fluorescent $\mathrm{CM}-\mathrm{H}_{2} \mathrm{DCFDA}$. The dye is a derivate of DCF-DA with an additional thiol reactive chloromethyl group enhancing the binding to intracellular components, thereby prolonging cellular retention of the dye. The nonfluorescent $\mathrm{CM}-\mathrm{H}_{2}$ DCFDA becomes fluorescent after deacetylation by cellular esterases and cellular oxidation by ROS. Fluorescence can be detected by a flow cytometer (FL1, green fluorescence). Cells $\left(1 \times 10^{5} / 100 \mu \mathrm{L}\right.$ RPMI) were incubated with $10 \mu \mathrm{M} \mathrm{CM}-\mathrm{H}_{2}$ DCFDA in the dark for $30 \mathrm{~min}$ at $37^{\circ} \mathrm{C}$. After washing of cells $400 \mu \mathrm{L}$ RPMI were added.

Adhesion molecules (FL1 and FL2), Annexin/PI (FL1 and FL2), and ROS (FL1) were measured using the FACScan (BD, Heidelberg, Germany).

All results are expressed as mean \pm SEM of $N$ independent experiments. The number of experiments is either given in the table or figures. SigmaStat Software was used to check statistical significance (Student's $t$-test and Mann-Whitney Rank Sum Test).

\section{Results and Discussion}

3.1. Cell Viability and Apoptosis after Plasma Treatment. Number of adherent cells after plasma treatment was used as sign for viability and calculated $1 \mathrm{~h}$ and $24 \mathrm{~h}$ after exposure of HaCaT cells to plasma. After $1 \mathrm{~h}(n=7)$ neither treatment with DBD/air nor with DBD/argon changed the number of cells recovered by detachment with trypsin/EDTA (treatment time up to $300 \mathrm{~s}$, data not shown). The recovery of $\mathrm{HaCaT}$ cells $24 \mathrm{~h}$ after treatment with DBD/air remained unchanged up to a treatment time of $40 \mathrm{~s}$ and was significantly reduced by a treatment time of $120 \mathrm{~s}$. A further decrease was observed by increasing the treatment time to $300 \mathrm{~s}$ (Figure 1(a)). Compared to $\mathrm{DBD} /$ air the use of argon as working gas resulted in a milder decrease of cell number. Only the longest treatment time resulted in a significant reduced cell recovery (Figure 1(a)). Similar results for detachment of adherent cells or impaired adhesion after the treatment of different cell types with different plasma sources were reported by several investigators [20-22, 35, 36]. Viability of treated cells strongly depended on the plasma source, the treatment time/plasma dose, the working gas (e.g., air versus argon), or treatment regimen [23].

Since a loss of HaCaT cells was caused by DBD plasma treatment cell death was further characterized by staining with PI to detect DNA and Annexin V to mark extracellular phosphatidylserine residues as sign for apoptosis. Twentyfour hours after treatment, nearly all detached/unsoldered cells were positive for Annexin $\mathrm{V}$ independent of whether the cells remained untreated (about $85.0 \%$ ) or were treated with DBD/air (>95.0\%) or DBD/argon plasma (>93.0\%). These cells were characterized by $25 \%$ to $35 \%$ early apoptotic cells (Annexin V positive, PI negative) and $60 \%$ to $75 \%$ late apoptotic/necrotic cells (Annexin V and PI positive; results not shown). Among the recovered adherent HaCaT cells early apoptotic cells increased slightly from $1 \%$ to about $3 \%$ (Figure 1(b)), while the amount of necrotic cells did not change significantly (data not shown). Only after a longer treatment time (20 min) apoptotic cells increase significantly (about $8 \%$ early apoptotic cells and 17\% necrotic cells) [28]. Treating $\mathrm{HaCaT}$ cells with DBD/argon apoptosis was not induced (data not shown). Detection of apoptosis in HaCaT cells is difficult; they seem to undergo apoptosis but then they detach very quickly. First results show a breakdown of the mitochondrial membrane potential as early sign of apoptosis in recovered adherent $\mathrm{HaCaT}$ cells after $1 \mathrm{~h}$ of a $300 \mathrm{~s}$ treatment cycle underlying that plasma induced apoptosis in $\mathrm{HaCaT}$ cells. Different cell types seem to react differently to exposure of plasma. While in primary immune cells $4 \mathrm{~h}$ after DBD/air plasma treatment the highest amount of Annexin ${ }^{+}$ cells was detected [23], in primary ocular cells highest proportion of apoptotic cells was already seen $2 \mathrm{~h}$ after treatment [37]. In primary porcine aortic endothelial cells apoptosis was detected $24 \mathrm{~h}$ after treatment [38]. Apoptosis induction was further observed in primary human lymphocytes [39] and in several cancer cell lines as melanoma cells [27, 40-42], colorectal cancer cells [43, 44], lung carcinoma cells [42], or breast cancer cells [45]. It is very difficult to compare these results since different plasma sources and different methods 


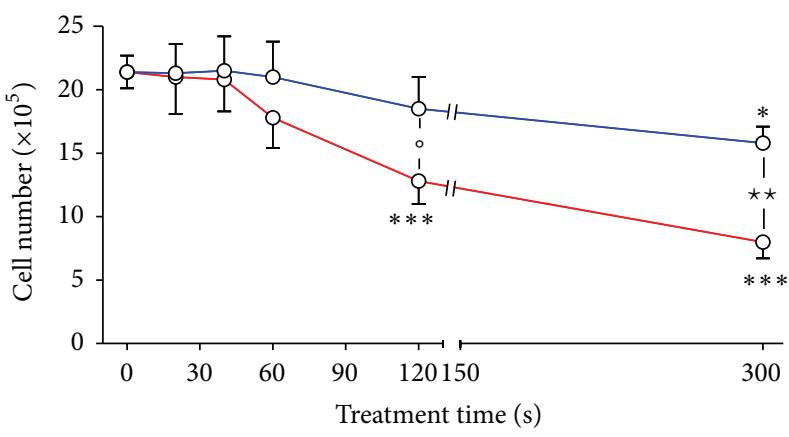

(a)

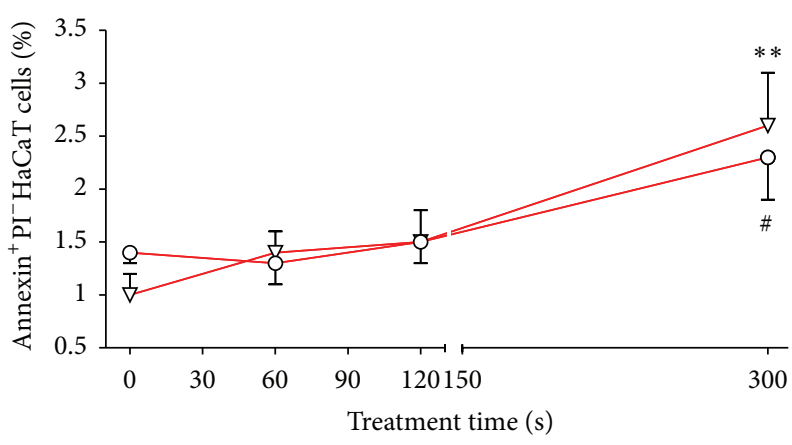

(b)

Figure 1: Cell number of recovered HaCaT cells (a) $24 \mathrm{~h}$ after treatment with surface DBD/air (red line; $N=8$ ) or DBD/argon (blue line; $N=8)$ plasma for $20 \mathrm{~s}$ to $300 \mathrm{~s}$ and induction of apoptosis (b) after DBD/air treatment $(\nabla=1 \mathrm{~h}$ after plasma treatment, $\mathrm{O}=24 \mathrm{~h}$ after plasma

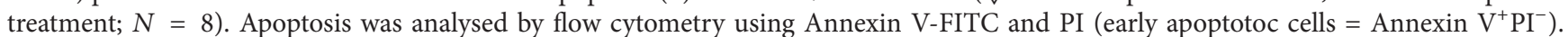
Untreated cells served as controls (see time 0 ). Results are given as mean \pm SEM. ${ }^{*} P<0.05,{ }^{* *} P<0.01,{ }^{* * *} P<0.001\left(t\right.$-test), ${ }^{*} P<0.05$ (Mann-Whitney test) versus control cells; ${ }^{\star} P<0.05,{ }^{\star *} P<0.01$ ( $t$-test); ${ }^{\circ} \mathrm{P}<0.05$ (Mann-Whitney test).

for apoptosis detection (e.g., Annexin V staining, TUNEL assay, SubG1 phase of cell cycle, caspase 3/7, cytochrome C release) were used. Further, the time of investigation after plasma treatment differed markedly, reaching from $1 \mathrm{~h}$ to $72 \mathrm{~h}$ after treatment.

3.2. Plasma and Expression of Adhesion Molecules. The first target of plasma during treatment of cells is the cell membrane with its embedded proteins as, for example, proteins for ion exchange, connecting molecules like integrins or cadherins, receptors (e.g., EGFR), or several enzymes. Their expression and activity can be regulated influencing cell adhesion, migration, ion conductivity, and cell signalling. Therefore, we investigated the expression of several integrins, of E-Cadherin, and that of the EGFR $24 \mathrm{~h}$ after plasma exposure.

Integrins as transmembrane adhesion receptors are composed of $\alpha$ - and $\beta$-subunits and mediate binding of cells to components of the extracellular matrix (ECM). Nearly all HaCaT cells expressed $\alpha_{2}$-integrin $(99.0 \% \pm 0.03 \%, n=14)$ and $\beta_{1}$-integrin $(98.9 \% \pm 0.02 \%, n=14)$ on their surface. This proportion was neither changed by treating the cells with DBD/air nor DBD/argon plasma (data not shown). Therefore, mean fluorescent intensity (MFI) of the integrin staining was estimated as relative indication for the amount of integrin molecules on the cell surface.

In control cells the MFI of $\alpha_{2}$-integrin amounted to about $70 \log U$ (Figure 2(a)) which was significantly enhanced by DBD/air treatment of adherent cells for $120 \mathrm{~s}$ and $300 \mathrm{~s}$. MFI of $\beta_{1}$-integrin on HaCaT cells was also increased, however, by a treatment time of $300 \mathrm{~s}$ only (Figure 2(b)). HaCaT cells treated with $\mathrm{DBD}$ /argon were characterized by a slight increase of $\alpha_{2}$-integrin at $300 \mathrm{~s}$ treatment and a stable $\beta_{1}$ integrin expression at all points of time tested (Figures 2(a) and 2(b)). Treating the same cells in suspension with DBD/air plasma MFI of $\alpha_{2}$-integrin decreased, while that of $\beta_{1}$-integrin also increased [23]. The kINPen 09, a plasma jet working with argon, caused no change in $\alpha_{2}$-integrin expression on $\mathrm{HaCaT}$ cells treated in suspension, while that of $\beta_{1}$-integrin increased [21]. The expression of $\alpha_{V^{-}}$and $\beta_{1}$-integrin on adherent fibroblasts treated with a plasma jet using helium as working gas was downregulated [24]. In human melanoma cells treated with helium plasma the expression of $\alpha_{2}$ - und $\alpha_{4}$-integrin was decreased [46]. Other integrins, however, were not investigated.

Since we found an increase in $\alpha_{2}$-integrin expression after treating $\mathrm{HaCaT}$ cells with $\mathrm{DBD} /$ air plasma further integrins were measured $24 \mathrm{~h}$ after $60 \mathrm{~s}$ and $300 \mathrm{~s}$ treatment cycles. A treatment time of $60 \mathrm{~s}$ had no influence on the expression of all integrins investigated (Figure 3 ). However, in addition to $\alpha_{2}$ - and $\beta_{1}$-integrin the expression of $\alpha_{5^{-}}, \alpha_{6^{-}}$, and $\beta_{3^{-}}$ integrins was significantly enhanced after a $300 \mathrm{~s}$ treatment cycle (Figure 3 ). In contrast, the expression of $\alpha_{3^{-}}, \alpha_{4^{-}}$, and $\alpha_{\mathrm{V}}$-integrins was not changed by DBD/air plasma treatment for $300 \mathrm{~s}$.

Different $\alpha$-subunits can covalently bind one $\beta$-chain, for example, $\alpha_{2} \beta_{1}, \alpha_{3} \beta_{1}, \alpha_{4} \beta_{1}, \alpha_{5} \beta_{1}, \alpha_{6} \beta_{1}$, or $\alpha_{\mathrm{V}} \beta_{1}$. These heterodimers bind to different components of the ECM. While the heterodimers $\alpha_{2} \beta_{1}$ and $\alpha_{6} \beta_{1}$ mediate binding to laminin, $\alpha_{4} \beta_{1}$ and $\alpha_{5} \beta_{1}$ predominantly bind to fibronectin [47]. The integrin receptor $\alpha_{2} \beta_{1}$ additionally binds to collagen. Cell spreading of $\mathrm{HaCaT}$ cells on fibronectin depends on, for example, the heterodimer $\alpha_{5} \beta_{1}$ integrin [48]. Especially at longer plasma treatment times, where the recovery of remaining cells is strongly decreased, expression of $\alpha_{2} \beta_{1}$, $\alpha_{5} \beta_{1}$, and $\alpha_{6} \beta_{1}$ heterodimers is enhanced, possibly to ensure adhesion of remaining cells. The integrin subunit $\alpha_{3}$ which was not influenced by plasma regulates events linked to epithelial repair including keratinocyte migration, thus promoting wound healing [49]. A loss of $\alpha_{3} \beta_{1}$ integrin would compromise intercellular adhesions and collective migration [49]. Cells which detached from the culture plate due to plasma treatment were not investigated in these experiments. However, we demonstrated a significant downregulation of $\alpha_{2}$-integrin on not-adhered HaCaT cells $24 \mathrm{~h}$ after treatment 


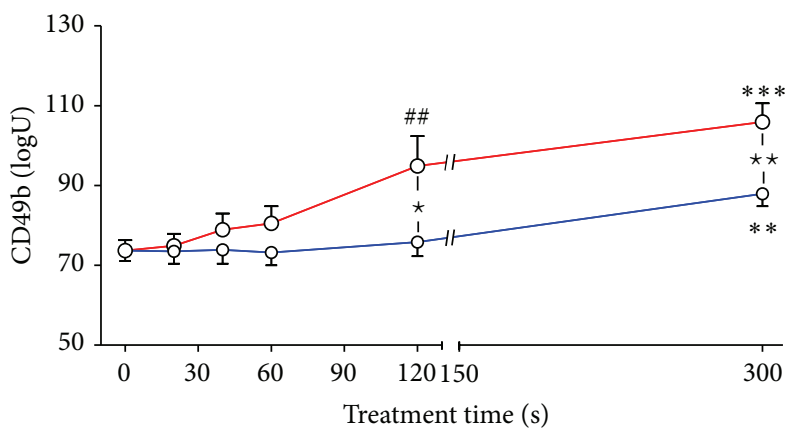

(a)

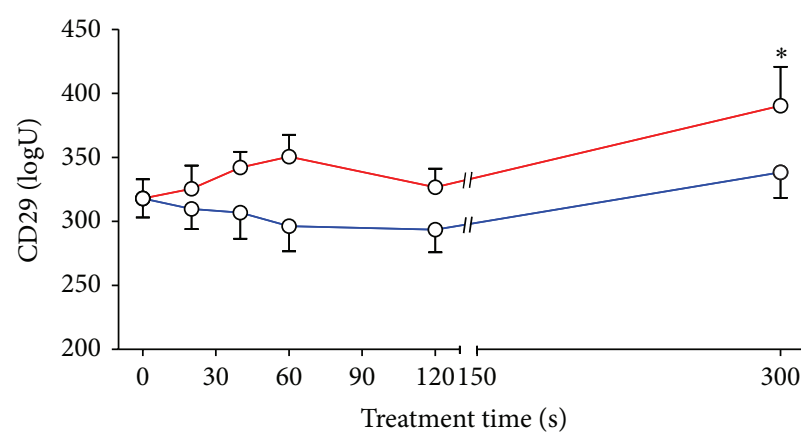

(b)

FIGURE 2: Expression of $\alpha_{2}$-integrin/CD49b (a) and $\beta_{1}$-integrin/CD29 (b) on HaCaT cells which were recovered by trypsin 24 h after treatment with surface DBD/air (red line; $N=8$ ) or DBD/argon (blue line; $N=7$ ) plasma. Cells were treated for $20 \mathrm{~s}$ to $300 \mathrm{~s}$. Untreated cells served as controls (see time 0). Expression of surface molecules was determined by flow cytometry using monoclonal antibodies. Mean fluorescence intensity (MFI) in $\log U$ of positive stained cells is presented (mean $\pm \mathrm{SEM}) .{ }^{*} P<0.05,{ }^{* *} P<0.01,{ }^{* * *} P<0.001\left(t\right.$-test); ${ }^{\# \#} P<0.01$ (Mann-Whitney test) versus control cells; ${ }^{\star} P<0.05,{ }^{\star \star} P<0.01$ ( $t$-test).

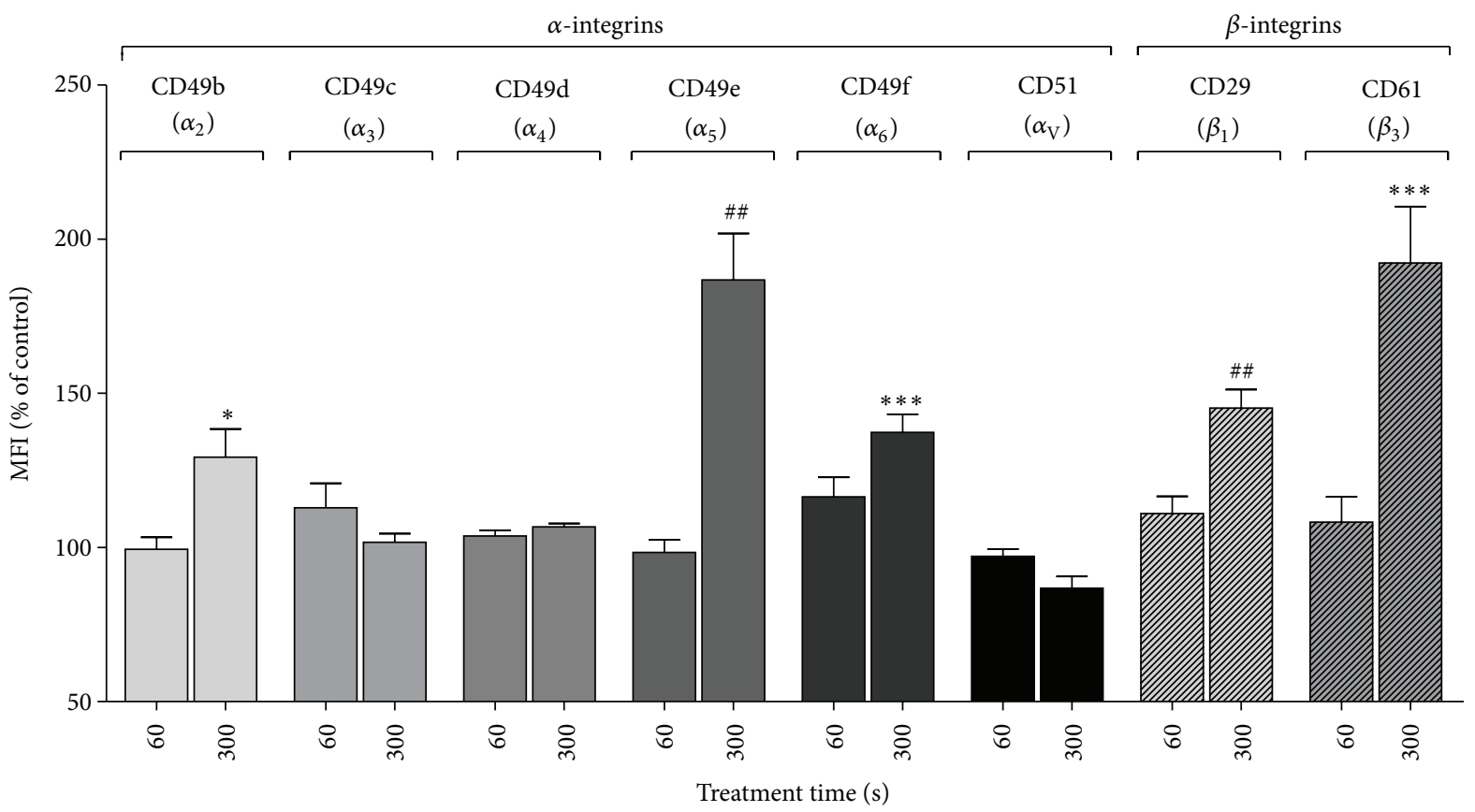

FIgURE 3: Expression of a panel of $\alpha$ - and $\beta$-integrins on HaCaT cells 24 h after treatment with surface DBD/air plasma $($ mean \pm SEM, $N=6)$ for $60 \mathrm{~s}$ and $300 \mathrm{~s}$. Expression of integrins determined by flow cytometry using monoclonal antibodies was measured as mean fluorescence intensity (MFI) of positive stained cells. The results of plasma treated cells are expressed as percentage of that of untreated control cells. ${ }^{*} P<0.05,{ }^{* * *} P<0.001$ (t-test); ${ }^{\# \#} P<0.01$ (Mann-Whitney test) versus control cells.

with the kINPen 09 while MFI of $\beta_{1}$-integrin was not influenced ([21], Supporting Information).

Cell-cell adhesion of remaining adherent cells seems not to be influenced by DBD plasma treatment since neither the proportion of E-cadherin expressing cells nor the density of this molecule on the surface of treated HaCaT cells is changed (data not shown). Similarly also the expression of the EGFR on HaCaT cells was neither influenced by the treatment time nor by the working gas used for generation of plasma. The EGFR important for proliferation and cell growth promotes cell survival. It contributes to motility of keratinocytes, for example, in wound healing [32]. One can conclude that on recovered HaCaT cells DBD plasma does not interfere with these fundamental requirements of cell survival. Widgerow [50] reported that within a chronic wound there is a failure in expressing appropriate levels of the $\alpha_{5}$-integrin subunit on epidermal keratinocytes resulting in downregulation of $\alpha_{5} \beta_{1}$ receptors. This might contribute to the healing defect in such wounds by altered stimulation of fibronectin and keratinocytes migration. Another receptor, $\alpha_{\mathrm{V}} \beta_{6}$, is of importance in chronic wounds. $\alpha_{\mathrm{V}} \beta_{6}$ integrin is an epithelial cell-specific receptor and not expressed on 
TABLE 1: Cell number of HaCaT keratinocytes and integrin expression on the cell surface $24 \mathrm{~h}$ after exposure to different stimuli. Cells were either treated for $300 \mathrm{~s}$ with DBD/air plasma (6 independent experiments), DBD/argon plasma (8 independent experiments), hydrogen peroxide (6 independent experiments), or ozone ( 2 independent experiments), which was generated by a Laboratory Ozonizer and monitored by FT-IR. Results are expressed as \% of untreated cells for plasma treatment and \% of oxygen (100\%) treated cells for ozone. n.d.: not determined.

\begin{tabular}{|c|c|c|c|c|c|c|c|}
\hline & \multicolumn{2}{|c|}{$\mathrm{DBD}$} & \multirow{2}{*}{$\begin{array}{c}\mathrm{H}_{2} \mathrm{O}_{2} \\
100 \mu \mathrm{M}\end{array}$} & \multicolumn{4}{|c|}{ Ozone (ppm) } \\
\hline & Air & Argon & & $\sim 100$ & $\sim 400$ & $\sim 1000$ & $\sim 1800$ \\
\hline Cell number ${ }^{1}$ & $22.5 \pm 3.0$ & $94.9 \pm 7.7$ & $38.1 \pm 3.2$ & $83.2 \pm 6.5$ & $62.1 \pm 5.2$ & $53.4 \pm 0.9$ & $42.2 \pm 1.7$ \\
\hline$\alpha_{2}$-Integrin $^{1}$ & $135.3 \pm 4.6$ & $117.9 \pm 6.8$ & $138.5 \pm 7.8$ & $102.5 \pm 1.3$ & $109.4 \pm 18.0$ & $115.4 \pm 8.2$ & $135.4 \pm 7.7$ \\
\hline$\alpha_{5}$-Integrin ${ }^{1}$ & $186.8 \pm 15.1$ & n.d. & $136.0 \pm 5.7$ & n.d. & n.d. & n.d. & n.d. \\
\hline$\alpha_{6}$-Integrin ${ }^{1}$ & $137.3 \pm 5.9$ & n.d. & $131.1 \pm 4.8$ & $94.7 \pm 17.4$ & $95.0 \pm 8.5$ & $79.8 \pm 2.3$ & $98.0 \pm 1.2$ \\
\hline$\beta_{1}$-Integrin $^{1}$ & $132.3 \pm 5.1$ & $104.8 \pm 4.0$ & $129.8 \pm 5.5$ & $98.6 \pm 3.6$ & $102.3 \pm 11.9$ & $104.5 \pm 7.9$ & $119.1 \pm 2.9$ \\
\hline$\beta_{3}$-Integrin $^{1}$ & $192.3 \pm 18.3$ & n.d. & $149.5 \pm 13.1$ & n.d. & n.d. & n.d. & n.d. \\
\hline
\end{tabular}

${ }^{1}$ Mean \pm SEM.

resting epithelium, but its expression is induced in chronic wounds [51]. Widgerow [50] stated that "the activation or inhibition of integrin receptors by various agents may provide an excellent means of influencing wound healing." DBD/air but not DBD/argon plasma increased the expression of $\alpha_{5}$ and $\beta_{1}$ integrins significantly. Integrin $\alpha_{\mathrm{V}}$ was decreased, however, not significantly. As demonstrated air plasma seems to be able to counteract the deleterious effects in chronic wounds, at least in terms of integrin expression.

3.3. Ozone and Integrin Expression. To determine whether or not ozone generated by plasma is responsible for increased integrin expression $\mathrm{HaCaT}$ cells were exposed to various concentrations of ozone. Prior to these experiments we measured the concentration of ozone accumulated in the gas phase during a $300 \mathrm{~s}$ treatment cycle (energy input about $9 \mathrm{~J} / \mathrm{cm}^{2}$ ) with DBD/air plasma in a closed system which amounted to about $100 \mathrm{ppm}$. A different DBD plasma source caused ozone concentrations of $182 \mathrm{ppm}\left(4.65 \mathrm{~J} / \mathrm{cm}^{2}\right)$ and of $30 \mathrm{ppm}\left(1.95 \mathrm{~J} / \mathrm{cm}^{2}\right)$ within $15 \mathrm{~s}$ [52]. Exposing HaCaT keratinocytes to about $100 \mathrm{ppm}$ ozone for $300 \mathrm{~s}$ more than $80 \%$ of adherent cells were recovered compared to the control, while after DBD/air plasma treatment for 300 s only $22.5 \%$ of cells were recovered (Table 1). In contrast to DBD/air treatment none of the integrins measured were influenced by 100 ppm ozone (Table 1). Using normal culture medium exposed to ozone and immediately applied to breast epithelial cells (MCF-10A), Kalghatgi et al. [52] could not detect any increase of $\gamma$-H2AX as sign for DNA damage. Increasing the ozone concentration up to 1800 ppm viability decreased continuously (Table 1 ). In contrast, only $\alpha_{2}$-integrin expression was similarly enhanced as after DBD/air treatment, while all other integrins investigated were not influenced (Table 1).

Taken together, although the ozone concentration with 100 ppm was 1000 times higher than the maximum allowable concentration (MAC), we could not detect any changes in the expression of those integrins which were enhanced by DBD/air plasma treatment.

3.4. Intracellular Reactive Oxygen Species and Integrin Expression. During plasma treatment the cells are exposed to all the electrons, ions, UV photons, short and long lived neutral and charged molecules such as ozone $\left(\mathrm{O}_{3}\right)$, hydroxyl and superoxide radicals $\left(\mathrm{HO}^{\bullet}, \mathrm{O}_{2}{ }^{--}\right)$, hydrogen peroxide $\left(\mathrm{H}_{2} \mathrm{O}_{2}\right)$, nitric oxide $\left(\mathrm{NO}^{\circ}\right)$, and singlet oxygen $\left({ }^{1} \mathrm{O}_{2}\right)$. Reactive oxygen species always present in cells have lots of physiological functions, for example, smooth muscle relaxation, control of ventilation, signal transduction from various membrane receptors, and enhancement of immunological functions [53]. Higher concentrations of ROS lead to DNA damage and consequently to apoptosis. We wanted to know whether or not these species from plasma penetrate into the treated cells or whether plasma induces ROS intracellularly. Both mechanisms cannot be distinguished by measuring intracellular ROS using $\mathrm{CM}-\mathrm{H}_{2} \mathrm{DCFDA}$, but this method gives a general indication of the oxidation state of the cells following plasma treatment. Using this dye $\mathrm{H}_{2} \mathrm{O}_{2}$, peroxynitrite anion $\left(\mathrm{ONOO}^{-}\right)$, and hydroxyl radical $\left(\mathrm{HO}^{\circ}\right)$, as well as alkylperoxyl and hydroxyl peroxyl radicals (ROO', $\mathrm{HOO}^{\circ}$ ) will be detected. Treating $\mathrm{HaCaT}$ cells with DBD/air a linear increase of CM- $\mathrm{H}_{2}$ DCFDA positive cells was observed $1 \mathrm{~h}$ after treatment (Figure 4(a)). Even $24 \mathrm{~h}$ later significant enhanced $\mathrm{CM}-\mathrm{H}_{2}$ DCFDA positive cells were still detectable (Figure 4(a)) suggesting a role for long lived radicals (e.g., $\mathrm{O}_{3}$, $\mathrm{NO}^{\circ}, \mathrm{H}_{2} \mathrm{O}_{2}$ ) in cells induced by plasma or partly developed from short lived radicals. Changing the working gas for generating plasma from air to argon there is nearly no increase in ROS positive cells neither $1 \mathrm{~h}$ nor $24 \mathrm{~h}$ after treatment (Figure 4(b)). Taking into account that air was completely replaced by argon (prior to spark the argon plasma) and, therefore, no oxygen exists in the gas phase over the cells, the induction of intracellular ROS can only be mediated by components of the culture medium. It was hypothesized by Arjunan et al. [54] that plasma-produced ROS, as well as products from plasma-ROS interaction with cell culture medium, either diffuse through cell membrane into the cytosol or react with the cell membrane to produce intracellular ROS. Vandamme et al. [44] detected measurable reactive oxygen species in the gas phase over the cells and in the culture medium. Recently, intracellular ROS were also detected in other human cells as in primary ocular cells (keratocytes), breast cancer cells (MCF-10A), HeLa cells, and in hepatocellular carcinoma cells (HepG2) [20, 26, 37, 55]. 


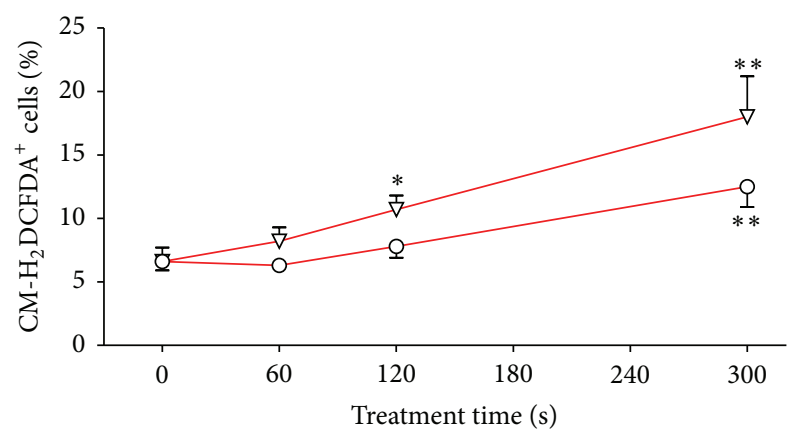

(a)

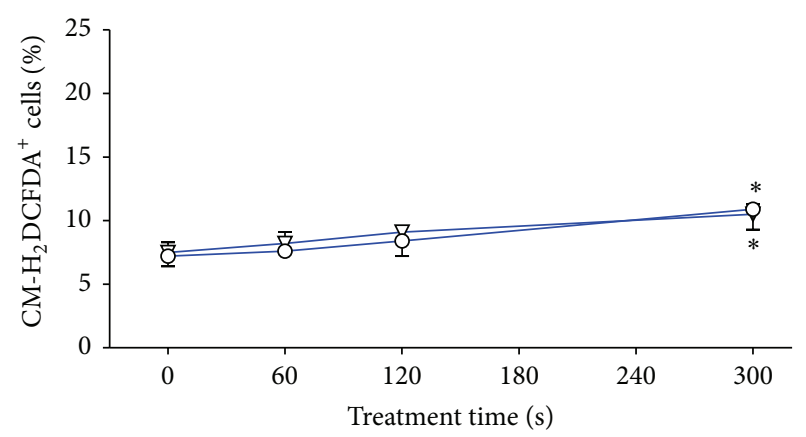

(b)

FIGURE 4: Induction of reactive oxygen species (ROS) within $\mathrm{HaCaT}$ cells by plasma. $\mathrm{HaCaT}$ cells remained either untreated (time 0 ) or were treated with DBD/air $((\mathrm{a}) ; \nabla=1 \mathrm{~h}$ after plasma treatment, $\mathrm{O}=$ $24 \mathrm{~h}$ after plasma treatment; $N=7$ ) or DBD/argon ((b); $\nabla=1 \mathrm{~h}$ after plasma treatment, $\mathrm{O}=24 \mathrm{~h}$ after plasma treatment; $N=7$ ) plasma for 60 to $300 \mathrm{~s}$. Intracellular ROS were detected by flow cytometry using the dye $\mathrm{CM}-\mathrm{H}_{2}$ DCFDA and results are given as mean \pm SEM. ${ }^{*} P<0.05,{ }^{* *} P<0.01$ versus control cells $(t$-test).

Highest levels of intracellular ROS were found shortly after plasma treatment and reached values of untreated control cells $24 \mathrm{~h}$ after plasma treatment. This is very similar to that we observed.

Due to the increase in intracellular ROS especially after DBD/air plasma treatment, we assume that the increased expression of integrins $\left(\alpha_{2}, \alpha_{5}, \alpha_{6}, \beta_{1}\right.$, and $\left.\beta_{3}\right)$ might be mediated by ROS. To verify this hypothesis $\mathrm{HaCaT}$ keratinocytes were treated for $24 \mathrm{~h}$ with $\mathrm{H}_{2} \mathrm{O}_{2}$. Induction of intracellular ROS was controlled and expression of those integrins which were significantly enhanced after DBD/air treatment for $300 \mathrm{~s}$ was measured. Hydrogen peroxide caused a nearly twofold increase of ROS positive HaCaT cells within $24 \mathrm{~h}(7.4 \pm 0.8 \%$ versus $14.2 \pm 1.6 \%, n=13, P<0.01$ ), which correlated well with that caused by DBD/air treatment for $300 \mathrm{~s}$ (Figure 4(a)). As shown in Table 1 hydrogen peroxide decreased the number of recovered cells to about $40 \%$. All integrins $\left(\alpha_{2}, \alpha_{5}, \alpha_{6}\right.$, $\beta_{1}$, and $\beta_{3}$ ) enhanced by treating $\mathrm{HaCaT}$ keratinocytes with $\mathrm{DBD} /$ air plasma are also enhanced by exposure to hydrogen peroxide (Table 1).

\section{Summary and Conclusion}

We provided basic investigations of HaCaT keratinocytes treated with nonthermal atmospheric-pressure plasma to get more insight into plasma-cell interaction. The first target of plasma in treating cells is the cell membrane which was influenced by DBD plasma. We demonstrated changes in the plasma membrane for phosphatidylserine residues as well as for some adhesion molecules, for example, the integrins, while E-cadherin and the EGFR were not affected. Changes in integrin expression were related to intracellular ROS induction, while ozone as nonradical ROS had no influence at concentrations measured during DBD/air treatment. Only a very high ozone concentration mediated increased $\alpha_{2}$ integrin expression.

Taken all our experiences together, we conclude that if the plasma treatment is long enough (e.g., $300 \mathrm{~s}$ ), intracellular ROS is enhanced, and it comes to a breakdown of the mitochondrial membrane potential as early sign of apoptosis and to DNA damage [28], followed either by cell death or an increased cell surface expression of several integrins on surviving cells. Shorter treatment periods $(<60 \mathrm{~s})$ do neither affect the remaining cell number, intracellular ROS, nor integrin expression. Since wound related cells are not negatively influenced by a milder plasma treatment and taking into account that plasma inactivates microorganisms, one can assume that chronic infected wound healing will be improved by plasma. However, further investigations are necessary to find optimal plasma treatment conditions, which initiate the relevant influence on integrin expression, but which should have less influence on cell viability and DNA.

\section{Abbreviations

$\begin{array}{ll}\text { ROS: } & \text { Reactive oxygen species } \\ \text { DBD: } & \text { Dielectric Barrier Discharge } \\ \text { PI: } & \text { Propidium iodide } \\ \text { ABP: } & \text { Annexin binding buffer } \\ \text { CM-H }{ }_{2} \text { DCFDA: } & 5 \text {-(and-6)-Chloromethyl-2' } 7^{\prime}{ }^{-} \\ & \text {dichlorodihydrofluorescein } \\ & \text { diacetate } \\ \text { EGFR: } & \text { Epidermal growth factor receptor } \\ \text { MFI: } & \text { Mean fluorescence intensity. }\end{array}$

\section{Conflict of Interests}

The authors state no conflict of interests.

\section{Acknowledgments}

This study was realized within the joint research project "Campus PlasmaMed" supported by the German Federal Ministry of Education and Research (Grant nos. 13N9774 and 13N9779). The authors thank Christiane Meyer and Rüdiger Titze (INP, Greifswald) for technical support in the treatment of cells with plasma, Lea Talmann for technical support in the treatment of cells with ozone, and Dr. Sabine Witt (Biometec GmbH, BioTechnikum Greifswald) for giving them the possibility of analysing their cells on the FACScan Cytometer. 


\section{References}

[1] T. Nosenko, T. Shimizu, and G. E. Morfill, "Designing plasmas for chronic wound disinfection," New Journal of Physics, vol. 11, Article ID 115013, 19 pages, 2009.

[2] S. A. Ermolaeva, A. F. Varfolomeev, M. Y. Chernukha et al., "Bactericidal effects of non-thermal argon plasma in vitro, in biofilms and in the animal model of infected wounds," Journal of Medical Microbiology, vol. 60, no. 1, pp. 75-83, 2011.

[3] G. Isbary, J. Heinlin, T. Shimizu et al., "Successful and safe use of 2 min cold atmospheric argon plasma in chronic wounds: results of a randomized controlled trial," British Journal of Dermatology, vol. 164, pp. 404-410, 2012.

[4] M. Polak, J. Winter, U. Schnabel, J. Ehlbeck, and K.-D. Weltmann, "Innovative plasma generation in flexible biopsy channels for inner-tube decontamination and medical applications," Plasma Processes and Polymers, vol. 9, no. 1, pp. 67-76, 2012.

[5] Y. F. Hong, J. G. Kang, H. Y. Lee, H. S. Uhm, E. Moon, and Y. H. Park, "Sterilization effect of atmospheric plasma on Escherichia coli and Bacillus subtilis endospores," Letters in Applied Microbiology, vol. 48, no. 1, pp. 33-37, 2009.

[6] G. Avramidis, B. Stüwe, R. Wascher et al., "Fungicidal effects of an atmospheric pressure gas discharge and degradation mechanisms," Surface and Coatings Technology, vol. 205, no. 1, pp. S405-S408, 2010.

[7] M. Hähnel, T. von Woedtke, and K.-D. Weltmann, "Influence of the air humidity on the reduction of Bacillus spores in a defined environment at atmospheric pressure using a dielectric barrier surface discharge," Plasma Processes and Polymers, vol. 7, no. 34, pp. 244-249, 2010.

[8] P. Y. Kim, Y.-S. Kim, I. G. Koo et al., "Bacterial inactivation of wound infection in a human skin model by liquid-phase discharge plasma," PLoS ONE, vol. 6, no. 8, Article ID e24104, 2011.

[9] A. Fröhling, M. Baier, J. Ehlbeck, D. Knorr, and O. Schlüter, "Atmospheric pressure plasma treatment of Listeria innocua and Escherichia coli at polysaccharide surfaces: inactivation kinetics and flow cytometric characterization," Innovative Food Science and Emerging Technologies, vol. 13, pp. 142-150, 2012.

[10] S. J. Sung, J. B. Huh, M. J. Yun, B. M. Chang, C. M. Jeong, and Y. C. Jeon, "Sterilization effect of atmospheric pressure nonthermal air plasma on dental instruments," Journal of Advanced Prosthodontics, vol. 5, pp. 2-8, 2013.

[11] S. G. Joshi, M. Paff, G. Friedman, G. Fridman, A. Fridman, and A. D. Brooks, "Control of methicillin-resistant Staphylococcus aureus in planktonic form and biofilms: a biocidal efficacy study of nonthermal dielectric-barrier discharge plasma," The American Journal of Infection Control, vol. 38, no. 4, pp. 293301, 2010.

[12] M. Y. Alkawareek, Q. T. Algwari, G. Laverty et al., "Eradication of Pseudomonas aeruginosa biofilms by atmospheric pressure non-thermal plasma," PLoS ONE, vol. 7, no. 8, Article ID e44289, 2012.

[13] K. Fricke, I. Koban, H. Tresp et al., "Atmospheric pressure plasma: a high-performance tool for the efficient removal of biofilms," PLoS ONE, vol. 7, no. 8, Article ID e42539, 2012.

[14] B. Finke, F. Luethen, K. Schroeder et al., "The effect of positively charged plasma polymerization on initial osteoblastic focal adhesion on titanium surfaces," Biomaterials, vol. 28, no. 30, pp. 4521-4534, 2007.

[15] G. Daeschlein, S. Scholz, R. Ahmed et al., "Skin decontamination by low-temperature atmospheric pressure plasma jet and dielectric barrier discharge plasma," Journal of Hospital Infection, vol. 81, pp. 177-183, 2012.

[16] H. R. Metelmann, T. von Woedtke, R. Bussiahn et al., "Experimental Recovery of $\mathrm{CO}_{2}$-Laser Skin Lesions by Plasma Stimulation," The American Journal of Cosmetic Surgery, vol. 29, pp. 52-56, 2012.

[17] J. Lademann, H. Richter, A. Alborova et al., "Risk assessment of the application of a plasma jet in dermatology," Journal of Biomedical Optics, vol. 14, no. 5, Article ID 054025, 2009.

[18] J. Lademann, C. Ulrich, A. Patzelt et al., "Risk assessment of the application of tissue-tolerable plasma on human skin," Clinical Plasma Medicine, vol. 1, pp. 5-10, 2013.

[19] J. W. Fluhr, S. Sassning, O. Lademann et al., "In vivo skin treatment with tissue-tolerable plasma influences skin physiology and antioxidant profile in human stratum corneum," Experimental Dermatology, vol. 21, no. 2, pp. 130-134, 2012.

[20] S. Kalghatgi, C. M. Kelly, E. Cerchar et al., "Effects of nonthermal plasma on mammalian cells," PLoS ONE, vol. 6, no. 1, Article ID e16270, 2011.

[21] B. Haertel, K. Wende, T. von Woedtke, K. D. Weltmann, and U. Lindequist, "Non-thermal atmospheric-pressure plasma can influence cell adhesion molecules on HaCaT-keratinocytes," Experimental Dermatology, vol. 20, no. 3, pp. 282-284, 2011.

[22] B. Haertel, F. Volkmann, T. von Woedtke, and U. Lindequist, "Differential sensitivity of lymphocyte subpopulations to nonthermal atmospheric-pressure plasma," Immunobiology, vol. 217, no. 6, pp. 628-633, 2012.

[23] B. Haertel, M. Hähnel, S. Blackert, K. Wende, T. von Woedtke, and U. Lindequist, "Surface molecules on HaCaT keratinocytes after interaction with non-thermal atmospheric pressure plasma," Cell Biology International, vol. 36, pp. 1217$1222,2012$.

[24] A. Shashurin, M. A. Stepp, T. S. Hawley et al., "Influence of cold plasma atmospheric jet on surface integrin expression of living cells," Plasma Processes and Polymers, vol. 7, no. 3-4, pp. 294300, 2010.

[25] S. Ptasińska, B. Bahnev, A. Stypczyńska, M. Bowden, N. J. Mason, and N. S. J. Braithwaite, "DNA strand scission induced by a non-thermal atmospheric pressure plasma jet," Physical Chemistry Chemical Physics, vol. 12, no. 28, pp. 7779-7781, 2010.

[26] M. Leduc, D. Guay, S. Coulombe, and R. L. Leask, "Effects of non-thermal plasmas on DNA and mammalian cells," Plasma Processes and Polymers, vol. 7, no. 11, pp. 899-909, 2010.

[27] G. J. Kim, W. Kim, K. T. Kim, and J. K. Lee, "DNA damage and mitochondria dysfunction in cell apoptosis induced by nonthermal air plasma," Applied Physics Letters, vol. 96, no. 2, Article ID 021502, 2010.

[28] S. Blackert, B. Haertel, K. Wende, T. von Woedtke, and U. Lindequist, "Influence of non-thermal atmospheric pressure plasma on cellular structures and processes in human keratinocytes (HaCaT)," Journal of Dermatological Science, vol. 70, pp. 173-181, 2013.

[29] D. A. Lauffenburger and A. F. Horwitz, "Cell migration: a physically integrated molecular process," Cell, vol. 84, no. 3, pp. 359-369, 1996.

[30] S. A. Illman, J. Lohi, and J. Keski-Oja, "Epilysin (MMP-28): structure, expression and potential functions," Experimental Dermatology, vol. 17, no. 11, pp. 897-907, 2008.

[31] S. Frøssing, B. Rønø, A. Hald, J. Rømer, and L. R. Lund, "Skin wound healing in MMP2-deficient and MMP2/Plasminogen double-deficient mice," Experimental Dermatology, vol. 19, no. 8, pp. e234-e240, 2010. 
[32] L. G. Hudson and L. J. McCawley, "Contributions of the epidermal growth factor receptor to keratinocyte motility," Microscopy Research and Technique, vol. 43, pp. 444-455, 1998.

[33] P. Boukamp, R. T. Petrussevska, D. Breitkreutz, J. Hornung, A. Markham, and N. E. Fusenig, "Normal keratinization in a spontaneously immortalized aneuploid human keratinocyte cell line," Journal of Cell Biology, vol. 106, no. 3, pp. 761-771, 1988.

[34] K. Oehmigen, M. Hähnel, R. Brandenburg, C. Wilke, K.-D. Weltmann, and T. von Woedtke, "The role of acidification for antimicrobial activity of atmospheric pressure plasma in liquids," Plasma Processes and Polymers, vol. 7, no. 3-4, pp. 250257,2010

[35] I. E. Kieft, J. L. V. Broers, V. Caubet-Hilloutou, D. W. Slaaf, F. C. S. Ramaekers, and E. Stoffels, "Electric discharge plasmas influence attachment of cultured CHO K1 cells," Bioelectromagnetics, vol. 25, no. 5, pp. 362-368, 2004.

[36] M. Hoentsch, T. von Woedtke, K.-D. Weltmann, and J. B. Nebe, "Time-dependent effects of low-temperature atmosphericpressure argon plasma on epithelial cell attachment, viability and tight junction formation in vitro," Journal of Physics D, vol. 45, no. 2, Article ID 025206, 2012.

[37] P. Brun, P. Brun, M. Vono et al., "Disinfection of ocular cells and tissues by atmospheric-pressure cold plasma," PLoS ONE, vol. 7, no. 3, Article ID e33245, 2012.

[38] S. Kalghatgi, G. Friedman, A. Fridman, and A. M. Clyne, "Endothelial cell proliferation is enhanced by low dose nonthermal plasma through fibroblast growth factor-2 release," Annals of Biomedical Engineering, vol. 38, no. 3, pp. 748-757, 2010.

[39] X.-M. Shi, G.-J. Zhang, Y.-K. Yuan, Y. Ma, G.-M. Xu, and Y. Yang, "Effects of low-temperature atmospheric air plasmas on the activity and function of human lymphocytes," Plasma Processes and Polymers, vol. 5, no. 5, pp. 482-488, 2008.

[40] G. Fridman, A. Shereshevsky, M. M. Jost et al., "Floating electrode dielectric barrier discharge plasma in air promoting apoptotic behavior in Melanoma skin cancer cell lines," Plasma Chemistry and Plasma Processing, vol. 27, no. 2, pp. 163-176, 2007.

[41] M. Keidar, R. Walk, A. Shashurin et al., "Cold plasma selectivity and the possibility of a paradigm shift in cancer therapy," British Journal of Cancer, vol. 105, no. 9, pp. 1295-1301, 2011.

[42] J. Y. Kim, J. Ballato, P. Foy et al., "Apoptosis of lung carcinoma cells induced by a flexible optical fiber-based cold microplasma," Biosensors and Bioelectronics, vol. 28, no. 1, pp. 333-338, 2011.

[43] C.-H. Kim, J. H. Bahn, S.-H. Lee et al., "Induction of cell growth arrest by atmospheric non-thermal plasma in colorectal cancer cells," Journal of Biotechnology, vol. 150, no. 4, pp. 530-538, 2010.

[44] M. Vandamme, E. Robert, S. Lerondel et al., "ROS implication in a new antitumor strategy based on non-thermal plasma," International Journal of Cancer, vol. 130, no. 9, pp. 2185-2194, 2012.

[45] S. J. Kim, T. H. Chung, S. H. Bae, and S. H. Leem, "Induction of apoptosis in human breast cancer cells by a pulsed atmospheric pressure plasma jet," Applied Physics Letters, vol. 97, no. 2, Article ID 023702, 2010.

[46] H. J. Lee, C. H. Shon, Y. S. Kim, S. Kim, G. C. Kim, and M. G. Kong, "Degradation of adhesion molecules of G361 melanoma cells by a non-thermal atmospheric pressure microplasma," New Journal of Physics, vol. 11, Article ID 115026, 13 pages, 2009.

[47] A. Van der Flier and A. Sonnenberg, "Function and interactions of integrins," Cell and Tissue Research, vol. 305, no. 3, pp. 285298, 2001.
[48] L. Koivisto, K. Larjava, L. Häkkinen, V.-J. Uitto, J. Heino, and H. Larjava, "Different integrins mediate cell spreading, haptotaxis and lateral migration of $\mathrm{HaCaT}$ keratinocytes on fibronectin," Cell Adhesion and Communication, vol. 7, no. 3, pp. 245-257, 1999.

[49] T. Wen, Z. Zhang, Y. Yu, H. Qu, M. Koch, and M. Aumailley, "Integrin $\alpha 3$ subunit regulates events linked to epithelial repair, including keratinocyte migration and protein expression," Wound Repair and Regeneration, vol. 18, no. 3, pp. 325334, 2010.

[50] A. D. Widgerow, 'Chronic wounds: is cellular 'reception' at fault? Examining integrins and intracellular signalling," International Wound Journal, vol. 10, pp. 185-192, 2013.

[51] J.-I. Jun and L. F. Lau, "Cellular senescence controls fibrosis in wound healing," Aging, vol. 2, no. 9, pp. 627-631, 2010.

[52] S. Kalghatgi, A. Fridman, J. Azizkhan-Clifford, and G. Friedman, "DNA damage in mammalian cells by non-thermal atmospheric pressure microsecond pulsed dielectric barrier discharged plasma is not mediated by ozone," Plasma Processes and Polymers, vol. 9, pp. 726-732, 2012.

[53] W. Dröge, "Free radicals in the physiological control of cell function," Physiological Reviews, vol. 82, pp. 47-95, 2002.

[54] K. P. Arjunan, G. Friedman, A. Fridman, and A. M. Clyne, "Non-thermal dielectric barrier discharge plasma induces angiogenesis through reactive oxygen species," Journal of the Royal Society Interface, vol. 9, no. 66, pp. 147-157, 2012.

[55] X. Yan, Z. Xiong, F. Zou et al., "Plasma-induced death of HepG2 cancer cells: intracellular effects of reactive species," Plasma Processes and Polymers, vol. 9, no. 1, pp. 59-66, 2012. 


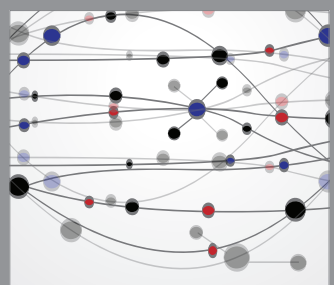

The Scientific World Journal
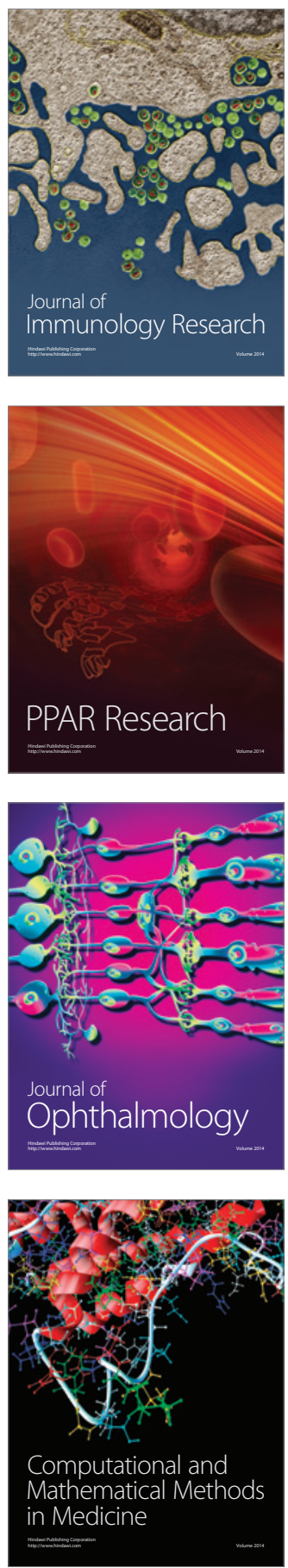

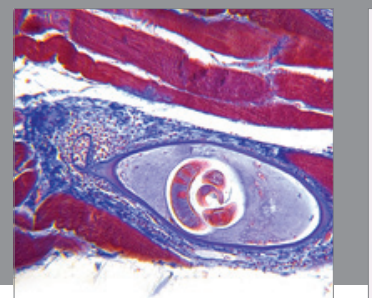

Gastroenterology

Research and Practice
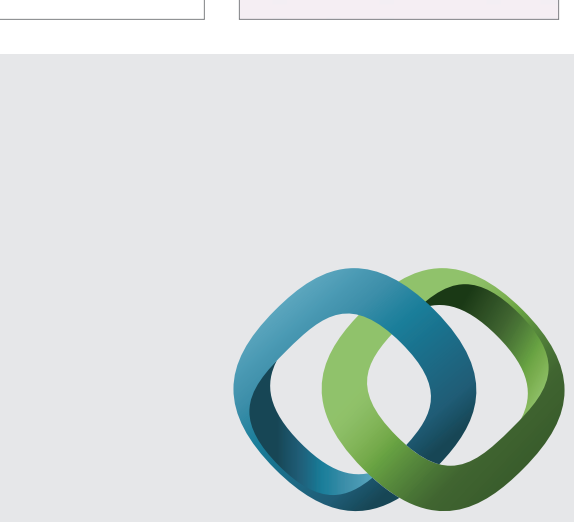

\section{Hindawi}

Submit your manuscripts at

http://www.hindawi.com
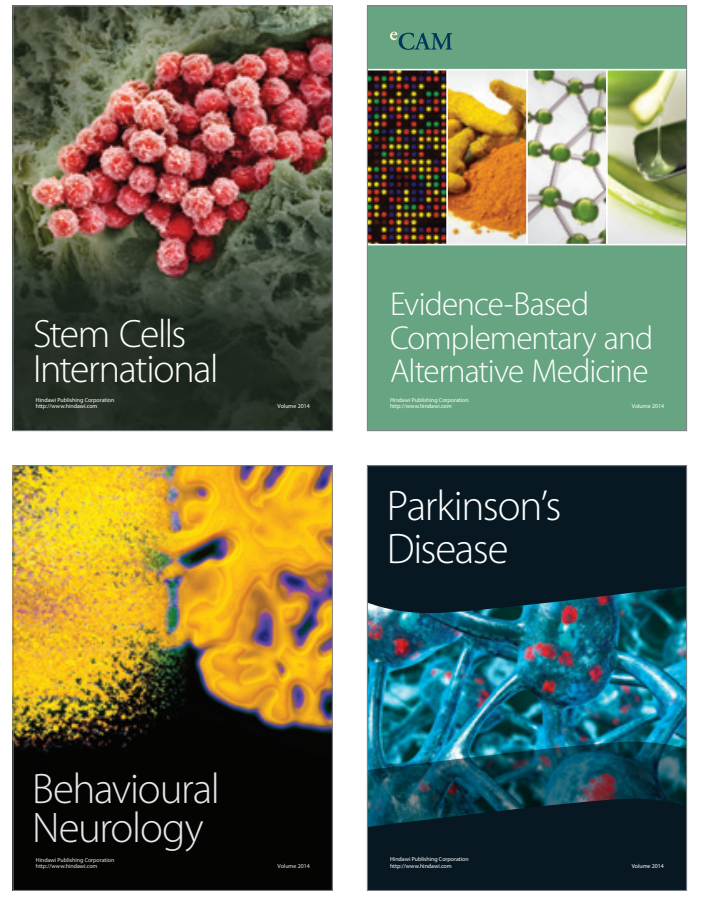
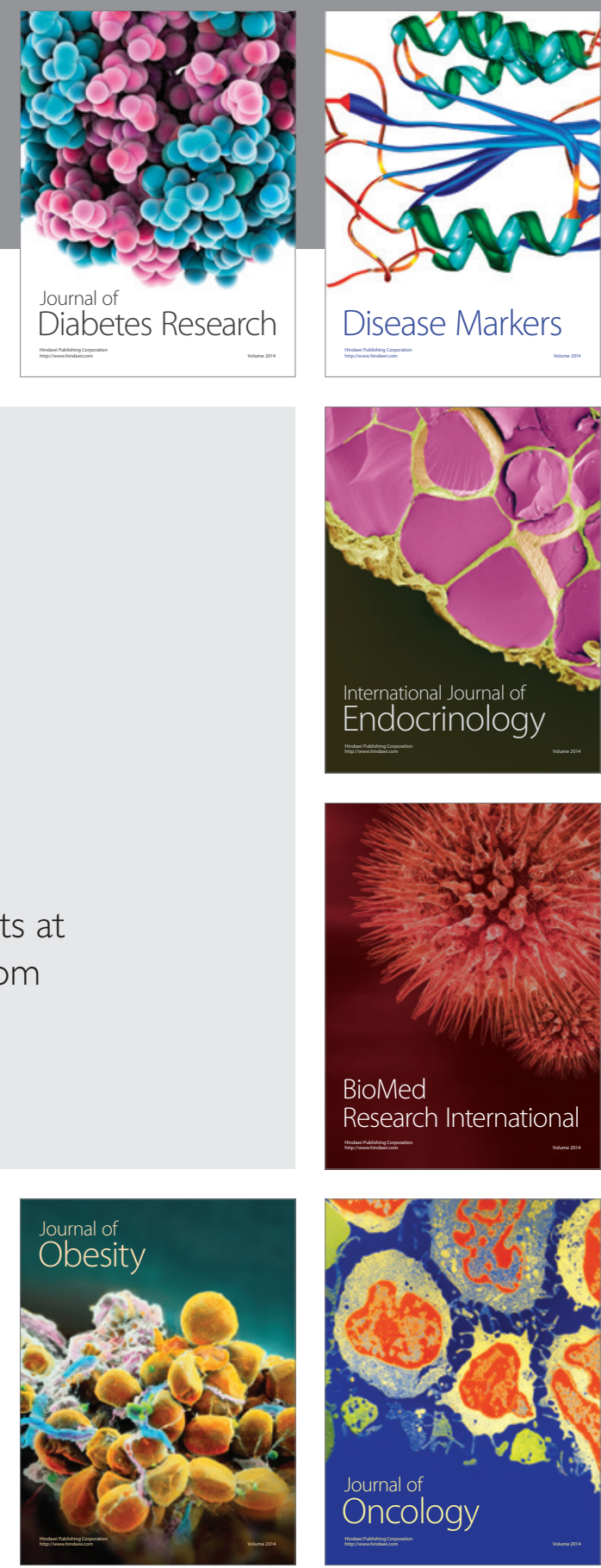

Disease Markers
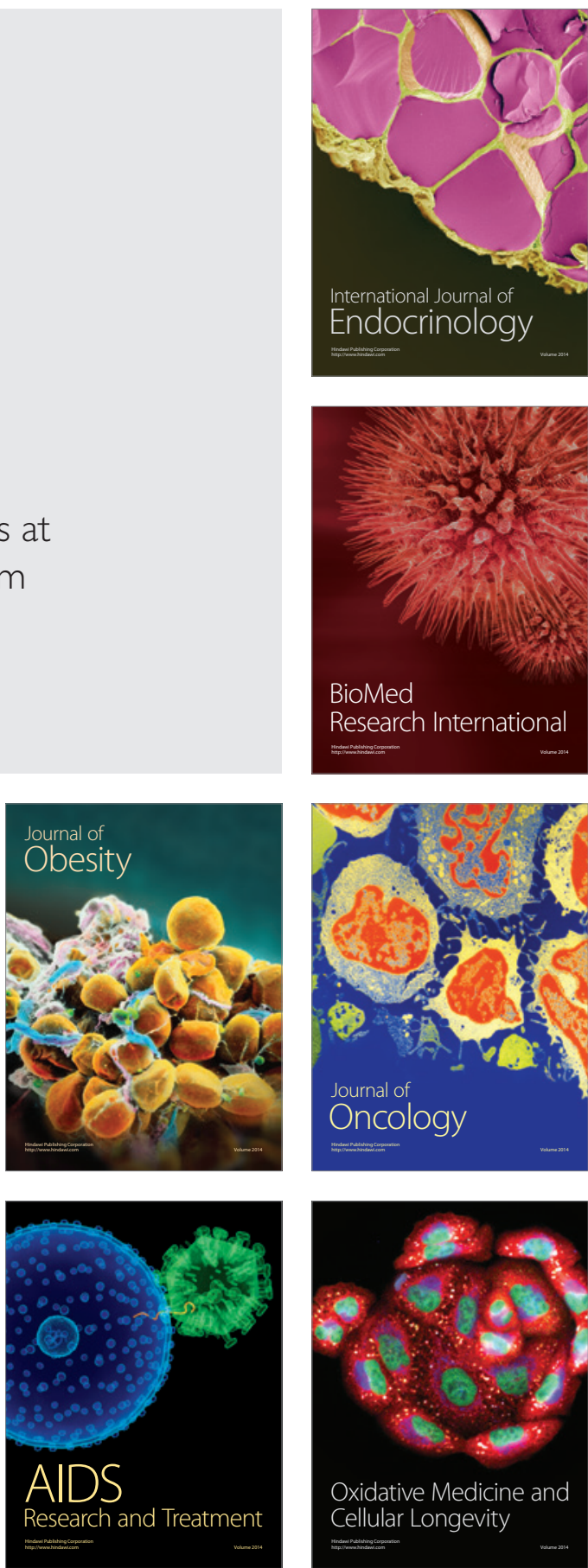